\title{
Transformational Leadership, Work Motivation and Organizational Culture on Employee Performance at Directorate General Rural Development Ministry of Villages
}

\author{
Maharani Gustianingtyas ${ }^{1}$, Farida Elmi ${ }^{2}$ \\ \{maharanigustianingtyas16@gmail.com¹, farida.elmi@mercubuana.ac.id² \\ Mercubuana University, Jakarta, Indonesia ${ }^{12}$
}

\begin{abstract}
This research aims to expose the impacts of transformational leadership style, work motivation, and organizational culture on employee performance at Directorate General Ministry of Villages, Development of Disadvantaged Regions and Transmigration. This research used quantitative research methods with type of causality research. Data collection techniques through questionnaires and documentary research then analyzed by Multiple Linear Regression Analysis. The results from this research was indicated that transformational leadership style had positive and significant impact on employee performance, work motivation had positive and significant influence on employee performance and organizational culture had positive and significant impact towards employee performance. Transformational leadership style is variable which has the greatest influence over employee performance.
\end{abstract}

Keywords: Transformational Leadership, Motivation, Organizational Culture, Performance

\section{Introduction}

\subsection{Background of Problem}

Human Resources (HR) in the context of state administration and development cannot be separated from government system that run. HR development in Indonesia is a must, because there's so many countries in the world today are compete to build and develop reliable human resources. To realize this, a commitment from all parties in the Ministries / Agencies is required to create effective and efficient governance. One aspect of an organization's HR strength was employee performance. To produce this optimal performance, it's also necessary to observed the appearance of employee when doing their jobs.

Based on data, it can be seen that performance achievements at Directorate General of Rural Area Development were fluctuated and unstable. With these fluctuations, it could be ascertained that the employee performance at Directorate General of Rural Area Development has not been going well and optimally. This needs to be considered because as organization that just transformed, there risk of performance declined sometimes occurred. To achieve those targets the Work Unit from Directorate General of PKP requires Human Resources (HR) who have the ability to carry out the main tasks and functions which have been set up. 


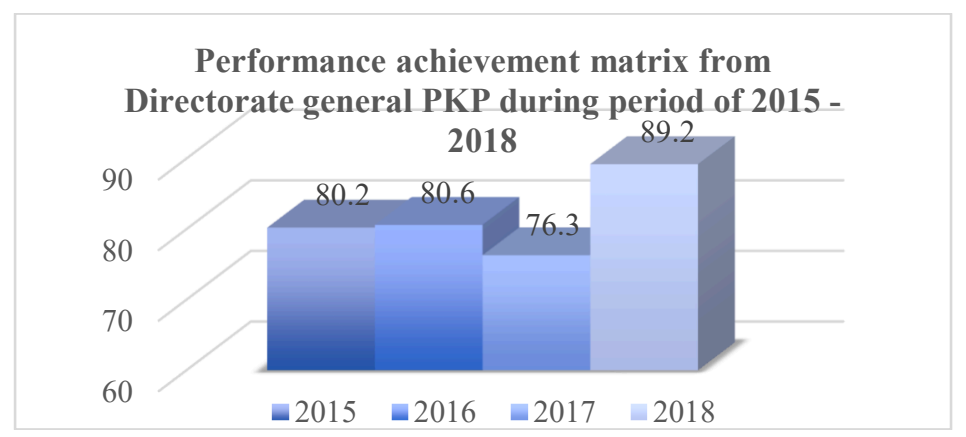

Fig 1. DG PKP Performance Achievement Matrix during 2015 - 2018

Based on data, it could be seen that employee attendance in one year each month was unstable and had experienced fluctuation. The absence from employee will have an impact towards performance which produced by Work Unit at Directorate General of PKP, that should be optimal less maximum, therefore the employee do not work in accordance with predetermined attendance standards.

Table 1. Recapitulation of employee attendance at Directorate General of PKP in 2018

\begin{tabular}{llllll}
\hline No. & Month & $\begin{array}{l}\text { Attendance } \\
\text { Ratio }\end{array}$ & No. & Month & $\begin{array}{l}\text { Attendance } \\
\text { Ratio }\end{array}$ \\
\hline 1 & January & $88 \%$ & 7 & July & $92.60 \%$ \\
\hline 2 & February & $92 \%$ & 8 & August & $91.17 \%$ \\
\hline 3 & March & $91.60 \%$ & 9 & September & $91.40 \%$ \\
\hline 4 & April & $93.70 \%$ & 10 & October & $95 \%$ \\
\hline 5 & Mei & $92 \%$ & 11 & November & $94 \%$ \\
\hline 6 & June & $91.40 \%$ & 12 & December & $94 \%$ \\
\hline
\end{tabular}

Source: Personnel and General Affairs Division of Directorate General of PKP (2018)

Based on data, it could be seen that the achievement of budget realization from Directorate General of PKP has not reached the target set every year. When seeing by these proportion from DG PKP Budget limit in 2016 and 2017 was decreased, due to a policy from Ministry of Finance in coordination with the National Development Planning Agency (Bappenas) for budget cuts including in implementation of assistance at Ministry of Villages, Development of Disadvantaged regions and Transmigration. The increased in proportion of Budget limit high up again in 2018, however, the realization of budget absorption continued declined. This indicated that employee performance had not optimal, both of managerial, administrative and technical sides.

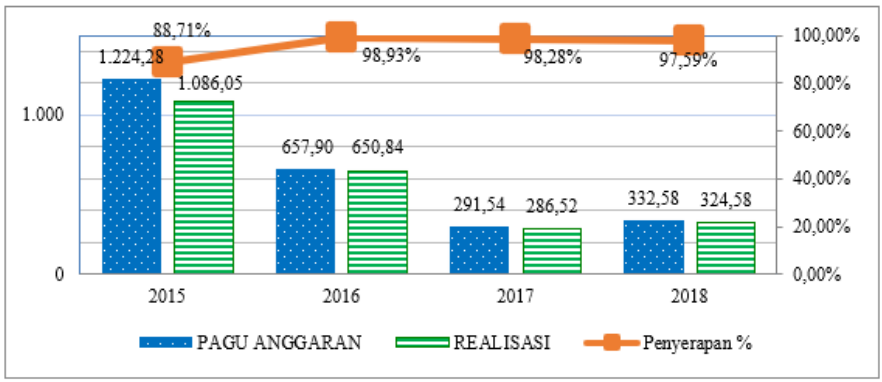

Fig 2. Directorate General of PKP Budget Realization 2015-2018 
Work motivation is the driving force for employee to achieve optimal performance. Beside that work motivation is one of important factors in organization, leadership style also another important factor to tied up the group together in organization, without an effective leadership style both formal and informal, members in organization will tend to have no direction, they would feel dissatisfied and less motivated. Transformational leadership styles could be determining those professional relationship between subordinates or employee at organization. Within the scope of the bureaucracy, it is also necessary to strengthen organizational culture and lead members' behavior and become an instrument with competitive advantage to support the organization's strategy in achieving performance targets and objectives, as well as to overcome organizational challenges quickly and precisely.

In line with the arguments above, the results of the study [1] suggest that transformational leadership partially has a positive and significant effect on employee performance. These findings are similar to those of studies [2], [3], and [4]. Regarding work motivation variables, several previous studies have shown that work motivation has a significant impact on employee performance. Research [5] shows that the relationship between motivation and employee performance is significant. These findings are similar to findings [6], and [7]. Previous research on the influence of organizational culture on performance was carried out by [8] that organizational culture has a significant effect on employee performance. These findings are similar to the results of research [9] which shows that organizational culture, teamwork, and organizational development have a direct and significant impact on human capital.

Though these transformational leadership style variable should have positive influence over employee performance, but prior research regarding employee performance which conducted by [10] shows that transformational leadership style had no significant impact compared to transactional leadership style towards employee performance who had low education also another prior research by [11], that shows if there had negative and insignificant influence between the transformational leadership style of employee performance, because employee satisfaction towards work has not been fulfilled. In the research with theme of the relationship between organizational culture and employee performance that conducted by [12], it was found if organizational culture had negative and insignificant impact on employee performance and research results from [13] stated that organizational culture had no impact towards employee performance.

Based on this explanation, the purpose of this research was to discover those significant influence from transformational leadership style to employee performance, to exposed about those significant impact from work motivation on employee performance and find out those significant influence from organizational culture over employee performance at Directorate General of Rural Area Development, Ministry of Villages, Development of Disadvantaged Regions and Transmigration.

\subsection{Transformational Leadership Style}

According to [14] transformational leadership is a leader who inspires his followers to go further with their own interests and who capable to have a profound and extraordinary influence against their followers. Research of [15] shows that transformational leadership positively impact towards organizational performance, though this transformational leadership style could be more important to shaping the performance result, The specific elements of intellectual stimulation and individual consideration appear to play an important role in shaping the results. 


\subsection{Work Motivation}

According to [14] motivation is a process which explained the strength, direction and persistence of a person in an effort to achieve goals. Motivation which stated by Robbins is the willingness to use high-level efforts for organizational goals, which is conditioned by the ability of the business to meet individual needs. In this definition there are three important elements, such as effort, goals, and needs. The business element is a measure of intensity. Effort which directed toward and consistent with the goals of organization is the type of effort that should be looking for and motivation is process to fill the needs. According to [16], the theory of motivation that's quite popular among management practitioners is the Herzberg Theory or called Two Factors Theory based on "motivators" and "hygiene factors", which defined that the relationship between individuals and their work is a basic relationship that their attitude over work could find out someone success and failure.

In the Herzberg theory, these two factors are called intrinsic factors and extrinsic factors. Work motivation also one of outputs from workers maintenance activities. According to [17], maintenance activities for Human Resources (HR) that could be done by companies with main goal, which is the persistence of Human Resources (HR) in carrying out the tasks which assigned to them. These maintenance activities include increasing the loyalty of human resources to the company, increasing the motivation and work discipline, improve morale and enthusiasm to work, increasing the sense of secure feeling, pride, and peace of mind of HR in doing work and increasing the whole of HR.

\subsection{Organizational Culture}

According to [14] organizational culture is a system of sharing meaning which carried out by members that distinguishes their organization from others. The dimensions that used in differentiating organizational culture are seven primary characteristics that collectively capture the essence of organizational culture including innovation and courage to take risks, attention to details, results orientation, people orientation, team orientation and aggressiveness.

\subsection{Performance}

According to [18] the term of performance comes from the word work performance or actual performance (work performance or actual achievement that someone has achieved). The definition of performance is the quality and quantity of work achieved by employee in carrying out the duties according to responsibilities that assigned to them. Based on [19] to measure the employee performance in organization, several indicators related to performance that can be used, such as quality, quantity (amount), time (period), cost reduction, supervision, and the relationship between colleagues.

The research theoretical framework model was described as in below:

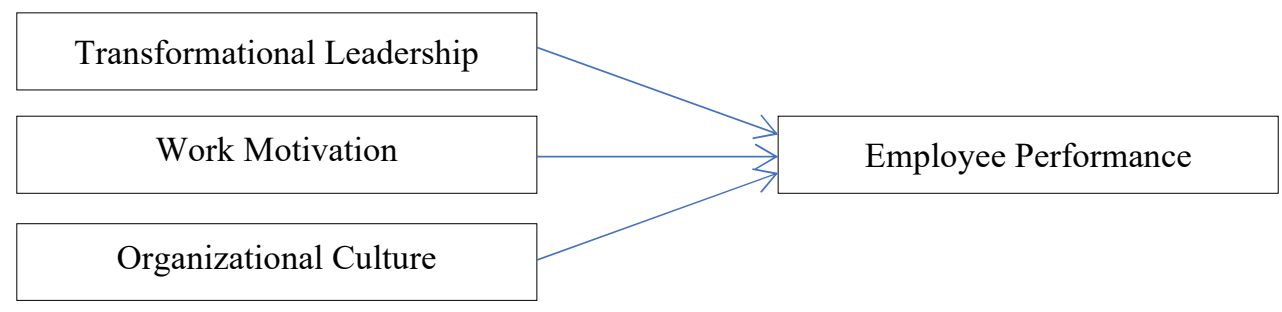


Based on those theoretical frameworks that has been described, a research hypothesis could be drawn, such as Transformational Leadership Style had significant impact over the Employee Performance at Directorate General of Rural Area Development, Work Motivation had significant impact towards Employee Performance at Directorate General of Rural Area Development, Organizational Culture had significant influence on Employee Performance at Directorate General of Rural Area and Development.

\section{Research Method}

This research used quantitative research methods with type of causality research. Based on [20] quantitative research emphasizes theory testing through numbers which are generally obtained through structured questions. In the same literature, it is explained that causality research is a type of research intended to explain one or more factors that cause problems. In other words, the purpose of causality research is to be able to state that variable $\mathrm{X}$ causes variable $\mathrm{Y}$. The population in this research were all Civil Servants (PNS) with positions of Echelon III, IV, and staff at Directorate General of Rural Area Development, Ministry of Villages, Development of disadvantaged regions and Transmigration, with amounted of 115 employees. Determination of these amount using non-probability sampling technique. The sample to be research as many as 89 respondents (Slovin, 5\% error tolerance).

These data analysis technique used multiple linear regression analysis. The use of multiple linear regression because this research used more than one independent variable, such as the Transformational Leadership Style variable (X1), Work Motivation (X2), Organizational Culture (X3) to discover its effect towards dependent variable, which is Performance (Y) at Directorate General of Rural Area Development, Ministry of Villages, Development of Disadvantaged regions and Transmigration.

\section{Results and Discussion}

Based on research result, all variables had $r$ count value $>r$ table $=0.208$. Thus all statement items of the Transformational Leadership Style (X1), Work Motivation (X2), Organizational Culture (X3) and Performance (Y) variables were declared valid. These Reliability Test results for all variables had Cronbach's Alpha value for more than 0.6 , thus Transformational Leadership Style (X1), Work Motivation (X2), Organizational Culture (X3) and Performance (Y) variables were declared reliable and could be carried out further analysis.

Based on research result, each relationship between Transformational Leadership Style (X1), Work Motivation (X2), and Organizational Culture (X3) towards Performance (Y) was significant, with these following interpretations: (1) These relationship between Transformational Leadership Style (X1) and Performance (Y) was significant of 8.377 with value at $\alpha=5 \%$, which is 1.98827 or rounded off to 1.99 with probability value or Sig. amounted to 0,000 . The coefficient value was positive, namely 0.410 that indicated that the direction of relationship between Transformational Leadership Style (X1) and Performance was positive of 41.0\%; (2) These relationship between Work Motivation (X2) and Employee Performance (Y) was significant of 2,612 with value of $\alpha=5 \%$, which is 1.98827 or rounded 
off to 1.99 and probability value or Sig. of 0.011 . The coefficient value was positive, namely 0.161 which indicate that the direction of relationship between Work Motivation (X2) and Employee Performance (Y) was positive of $16.1 \%$; (3) The relationship between Organizational Culture (X3) and Employee Performance (Y) had significant of 3,747 with value of $\alpha=5 \%$, namely 1.98827 or rounded off to 1.99 and probability value or Sig. amounting to 0,000 . The coefficient value was positive, which is 0.182 and it was indicated that the direction of relationship between Organizational Culture (X3) and Employee Performance (Y) was positive of $18.2 \%$.

Table 2. Analysis of t test result

\begin{tabular}{llcccc}
\hline \multicolumn{1}{c}{ Model } & \multicolumn{2}{c}{ Unstandardized Coefficients } & \multirow{2}{*}{ t } & \multirow{2}{*}{ Sig. } \\
\cline { 2 - 4 } & B & Std. Error & & & \\
\hline \multirow{2}{*}{ (Constant) } & 1.281 & 0.186 & 6.895 & 0.000 \\
Transformational Leadership & 0.410 & 0.049 & 8.377 & 0.000 \\
$\quad$ Work Motivation & 0.161 & 0.062 & 2.612 & 0.011 \\
$\quad$ Organizational Culture & 0.182 & 0.049 & 3.747 & 0.000 \\
a. Dependent Variable: Employee Performance & & & & \\
\hline
\end{tabular}

Furthermore, to measure how far the model's ability to explain these variations of dependent variable $(Y)$, the coefficient of determination test was performed. Based on result, it is known that the value of $\mathrm{R}$ Square $\left(\mathrm{R}^{2}\right)$ obtained was 0.737 or equal to the coefficient of determination of $73.7 \%$.

Table 3. The Results of $\mathrm{R}^{2}$ Coefficient of Determination Performance

\begin{tabular}{|c|c|c|c|c|}
\hline \multicolumn{5}{|c|}{ Model Summary } \\
\hline Model & $\mathrm{R}$ & R Square & Adjusted R Square & Std. Error of the Estimate \\
\hline 1 & $.858^{\mathrm{a}}$ & 0.737 & 0.728 & 0.235 \\
\hline $\begin{array}{l}\text { Predicto } \\
\text { Depend }\end{array}$ & $\begin{array}{l}\text {, Orgat } \\
\text { Perforn }\end{array}$ & Iture, Work & vation, Transformatic & l Leadership \\
\hline
\end{tabular}

The correlation analysis between the dimensions of the independent variable and the dependent variable can be translated into the inter-dimensional correlation matrix. Based on result, it is known that the greatest correlation value between the dimensions in Transformational Leadership Style variable (X1) towards Performance variable (Y) was the dimension X1.1which is Ideal influence with the Y1 dimension Quality of 0.751 and falls into the category of level strong relationship while the value of the greatest correlation between the dimensions in Work Motivation variable (X2) to the Performance variable (Y) was X2.2 namely Extrinsic Motivation to Y1 Quality dimension of 0.572, and falls into the medium category. The greatest correlation value between the dimensions in the Organizational Culture variable (X3) towards Performance variable (Y) was the X3.1 dimension namely Innovation and the Courage to Take Risks to Y1 Dimension of Quality of 0.527 and it is included in moderate category.

\subsection{Discussion}

Transformational Leadership Style had significant and very strong influence towards employee performance. This research confirms those statement from [4] and [15] research which found that transformational leadership styles had positive and significant impact towards employee performance. When seeing from the results of correlation between dimensions, transformational leadership style has the greatest influence towards performance in the dimensions of ideal influence on performance "quality", it can be explained that the leadership at Directorate General of Rural Area Development, Ministry of Village, 
Development of Disadvantaged regions and Transmigration was a leader who has huge influence. The ideal is a leader who has visionary or clear vision towards goals, so that the leader can transform the ideal thinking that comes from himself in results of interactions with their subordinates, then the collaboration would produce good quality performance.

Work motivation had significant influence with moderate level of correlation on employee performance at Directorate General of Rural Area Development, Ministry of Villages, PDT and Transmigration. This result was in line with [7]. When seeing from these correlation between dimensions result, the work motivation variable which has greatest influence on performance is the dimension of extrinsic motivation to the quality of performance, it could be explained that employee at Directorate General of Rural Area Development, Ministry of Village, Development of Disadvantaged regions and Transmigration felt Motivated to work because of encouragement that comes from outside, for example life at work (office life) at Directorate General of Rural Area Development has very familial atmosphere, so employee are quite easy to adapt.

Besides that, these days the job as Civil Servant (PNS) is very much in demand by most people in Indonesia who feel the benefits are sufficient until the end of the employee's life, for example, it is clear that the regulations or policies for various levels of civil servant positions in distribution of salaries and benefits (salary and benefits) also get a pension fund. From a small part of this entrepreneurial motivation, employee at Directorate General of Rural Area Development were motivated to complete their performance with good quality performance. The results from correlation test were indicate that organizational culture had significant influence with a strong level of correlation to employee performance.

This research confirms the research which conducted by [12]. If seen from the correlation between dimensions result, organizational culture variables which has greatest influence on performance were the dimensions of innovation and the courage to take risks on quality in performance variable, it could be explained that to improve the quality of performance at Directorate General of Rural Area Development, there should be improved " innovation in work and courage in taking risks". Employee at Directorate General of Rural Area Development not only follow regulations and instructions simply because they feel they don't need to think hard to improvise and innovate, but as civil servants it needs to growth the intrapreneurship to stimulate a sense of innovation in being fully responsible to the country, whereas the employees were ready to face the changes which occur in the country.

\section{Conclusions}

Based on data processed result and analysis, it could be drawn that Transformational leadership style variable has a significant impact toward employee performance; Work motivation variable has a significant impact towards employee performance; Organizational culture variable has a significant influence towards employee performance.

The results of multiple linear regression analysis and inter-dimensional correlation show that transformational leadership style, work motivation, and organizational culture significantly influence employee performance. To increase the significance value, agencies need to : Encouraging subordinates to be more creative, such as being involved in giving their opinions in meetings which held by internal and external agencies, leader should provide opportunities for subordinates to be able to develop their potential through Education and Training (Diklat) or Learning Programs which held by agencies or outside agencies; Considering and improving the quality of employee performance, for example, such as 
security of the work environment and working conditions such as lighting, workspace, away from noise and cleanliness of workplace facilities and infrastructure; Providing socialization to all employee so they would understand the main duties and functions of each employee, and subordinates do not just wait for the disposition of the boss.

Beside that by providing socialization related to main tasks and functions, and need to conduct training which related to intrapreneurship that would be strategy to stimulate employee innovation using the talents within them, also to stimulate employee who have bright ideas to delivered it into work and develop in their main duties and functions, of course, it still required adjusted to leadership policies or company.

\section{References}

[1] Nasution, MI 2018, 'Peran Kepuasan Kerja dan Kepemimpinan Transformasional Terhadap Kinerja Karyawan', Prosiding: The National Conferences Management and Business (NCMAB) "Pemberdayaan dan Penguatan Daya Saing Bisnis Dalam Era Digital". hal. 425439.

[2] Umaternate, AR, Elmi, F 2017, 'Pengaruh Gaya Kepemimpinan Transformasional, Disiplin Kerja dan Penempatan Kerja Terhadap Kinerja Karyawan FPG Insurance', Jurnal SWOT, vol. VII, no. 2, hal. 273-287.

[3] Nugroho, RE 2019, 'Pengaruh Gaya Kepemimpinan Transformasional, Stress Kerja, dan Budaya Organisasi Terhadap Kinerja Karyawan Kontrak Proyek’, Jurnal Ilmiah Manajemen, vol. 9, no. 2, hal. 341-354.

[4] Al Fath, MR, Saragih, R 2019, 'The Effect of Transformational Leadership Style to Employees Performance at PT PLN Pusat Pemeliharaan Listrik Bandung', e-Proceeding of Management, vol. 6, no. 1, pp. 1126-1132.

[5] Zameer, H, Ali, S, Nisar W, Amir, M 2014, 'The Impact of the Motivation on the Employee's Performance in Beverage Industry of Pakistan', International Journal of Academic Research in Accounting, Finance and Management Sciences, vol. 4, no. 1, pp. 293-298.

[6] Primandaru, DL, Tobing, DSK, Prihatini, D 2018, 'Pengaruh Motivasi Kerja dan Lingkungan Kerja Terhadap Kepuasan Kerja, Disiplin Kerja dan Kinerja Karyawan PT. Kereta Api Indonesia (Persero) DAOP IX Jember', Jurnal Bisnis dan Manajemen, vol. 12, no. 2, hal. 204211.

[7] Tulhusnah, L, Sularso, RA, Fathorrazi, M 2018, 'Pengaruh Kepemimpinan dan Motivasi Kerja Terhadap Kepuasan Kerja dan Kinerja Pegawai pada Kantor Badan Pertanahan Nasional Kabupaten Situbondo', Jurnal Ekonomi dan Bisnis GROWTH (JEBG), vol. 16, no. 1, hal. 1828.

[8] Sagita, AA, Susilo, H, Cahyo WS, M 2018, 'Pengaruh Budaya Organisasi Terhadap Kinerja Karyawan Dengan Motivasi Kerja Sebagai Variabel Mediator (Studi Pada PT. Astra Internasional, Tbk-Toyota (Auto 2000) Cabang Sutoyo Malang)', Jurnal Administrasi Bisnis (JAB), vol. 57, no. 1, hal. 73-82.

[9] Ghorbanhosseini, M 2013, 'The Effect of Organizational Culture, Teamwork and Organizational Development on Organizational Commitment: The Mediating Role of Human Capital', Technical Herald, vol. 20, no. 6, pp. 1019-1025.

[10] Setiawan, EY 2015, 'Pengaruh Gaya Kepemimpinan Transformasional dan Transaksional Terhadap Kinerja Karyawan PT. ISS Indonesia di Rumah Sakit National Surabaya’, e-Jurnal Ilmu Manajemen MAGISTRA, vol. 1, no. 1, hal. 31-41.

[11] Aqmarina, N.S, Utami, H.N, Prasetya, A, 'Pengaruh Kepemimpinan Transformasional dan Transaksional Terhadap Kepuasan Kerja dan Kinerja Karyawan', Jurnal Administrasi Binsis (JAB), vol. 35, no. 2, hal. 164-173.

[12] Maabuat, ES 2016, 'Pengaruh Kepemimpinan, Orientasi Kerja, dan Budaya Organisasi Terhadap Kinerja Pegawai (Studi pada Dispenda Sulut UPTD Tondano), Jurnal Berkala Ilmiah Efisiensi, vol. 16, no. 01, hal. 219-231. 
[13] Pratiwi, PAL, Lengkong, VPK, Mintardjo, CMO 2017, 'Pengaruh Orientasi Kerja dan Budaya Organisasi Terhadap Kinerja Karyawan (Studi pada PT. PLN Persero Wilayah Suluttenggo Area Manado', Jurnal EMBA, vol. 5, no. 2, hal. 1193-1204.

[14] Robbins, SP, Judge, TA 2015, Perilaku Organisasi. Jakarta:Salemba Empat.

[15] Orabi, TGA 2016, 'The Impact of Transformational Leadership Style on Organizational Performance: Evidence from Jordan', International Journal of Human Resource Studies, vol. 6, no. 2, pp. 89-102.

[16] Wibowo, 2016, Manajemen Kinerja Edisi Kelima. Jakarta:Raja Grafindo Persada.

[17] Elmi, F 2018, Telisik Sumber Daya Manusia. Jakarta:Mitra Wacana Media.

[18] Mangkunegara, AA, Prabu, A 2016, Manajemen Sumber Daya Manusia Perusahaan. Bandung:Remaja Rosdakarya.

[19] Kasmir, 2016, Manajemen Sumber Daya Manusia (teori dan praktek). Jakarta:Raja Grafindo Persada.

[20] Sekaran, U, Bougie, R 2019, Metode Penelitian untuk Bisnis Edisi 6 Buku 1. Jakarta:Salemba Empat. 